\title{
The influences of gender and income inequality on cross-national variations in lethal violence
}

\author{
Margrét Valdimarsdóttir, Doctoral Candidate in Criminology at the City \\ University of New York, Project Manager at the Social Science Research \\ Institute at the University of Iceland
}

\begin{abstract}
The current research examines the cross-national relationship between income and gender inequality as well as their interconnected influences on both female and male homicide victimization. Using a sample of 127 heterogeneous countries, this research supports previous studies that economically stratified societies tend to have high levels of lethal violence. The study also finds that economically stratified societies tend to be male-dominated, which is also associated with increased violence against women as well as increased male-onmale violence.
\end{abstract}

Keywords: Violence; violence against women; male-on-male violence; gender inequality; income inequality; masculinity; criminology.

\section{Introduction}

Violence continues to be a serious public health problem across the globe, causing disabilities and other long-term physical and mental health related problems (Wolf, Gray \& Fazel 2014). Globally, men represent 95 percent of those convicted of lethal violence (UNODC 2013). However, the rates at which men are violent vary greatly from one place to another as well as across different times in history. Instead of asking why some countries have more violence than other countries, the more appropriate question may be why so many men in some societies use violence. Scholars have generally rejected the

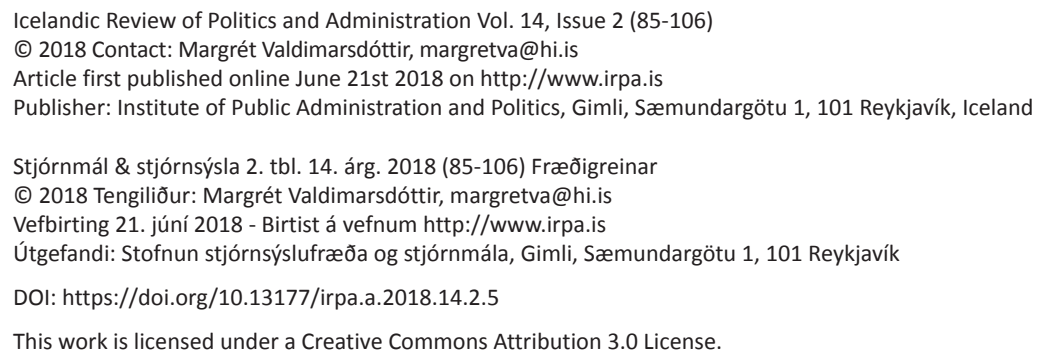


idea that men are naturally aggressive. As Janet Katz and William Chambliss (cited in Messerschmidt 1993, 25) concluded after their extensive examination of research on biology and crime, "[a]n individual learns to be aggressive in the same manner that he or she learns to inhibit aggression. One is not a natural state, and the other culturally imposed".

The link between aggressiveness and fundamental cultural ideas regarding what it means to be a man may be a contributing factor in the high rates of violence in certain societies. Thus, a gendered perspective in research on cross-variations in violence may be particularly important, not just in explaining female victimization but also male violence against other men (Schwartz \& Steffensmeier 2015). Although there is still scarce theoretical work on how structural gender inequality could be linked to male-on-male violence, the literature on the social construction of masculinities has provided a key in understanding how the gendered nature of societies impacts how men express masculinity and thus their behavior towards each other (e.g. Connell 1995, 2000, 2002; Kimmel \& Messner 2001; Messerschmidt 1993).

Feminist scholars (e.g., Brownmiller 1975; Hester, Kelly \& Radford 1996) have argued that women in societies where their economic, political and social status is relatively weak are more likely to experience violence than women in more gender equal societies. Violence against women may be tolerated as a part of life in male dominated societies and have insignificant consequences for male offenders in the criminal justice system (Barbaret 2014; Yodanis 2004). Cross-national research on the link between gender inequality and violence against women has reported mixed results (Yodanis 2004; Gartner 1990; Chon 2013a; Lee \& Shihadeh 1998; Stamatel 2014). Most prior studies relied on a single measure of female work participation or education as a measure of gender inequality and a small sample of mostly western countries, which limits their ability to draw general conclusions.

One of the most consistent finding in cross-national research on violence is that income inequality is associated with high homicide rates (see reviews in Koeppel, Rhineberger-Dunn \& Mack 2015; Nivette 2011; LaFree 1999; Pickett \& Wilkinson 2015). Income inequality may, indeed, also be linked to gender inequality. Wilkinson (1996, 2005), one of the leading scholars on the negative consequences of economic inequality, has argued that as men have traditionally been the family's primary breadwinner, economic inequality will have a greater impact on them than on women. Poor men who feel subordinated and disrespected in economically stratified societies may, however, try to attain a sense of authority by subordinating women (Wilkinson 2005).

Moreover, because economic inequality is promoted and reinforced in societies that are characterized by competitive individualism and an orientation toward monetary achievement (Messner \& Rosenfeld 1997, 2007; Currie 1997), it is assumed to be related to cultural ideologies that are linked to traditional masculinity, thus further increasing male dominance in the culture (Wilkinson 2005).

The present study contributes to cross-national research on lethal violence by comparing the impact that both income- and gender inequality have on female and male homicide victimization. I also examine the interconnected influences of income- and 
gender inequality on homicide by testing indirect (mediation) effects. In other words, I expect income inequality to influence homicide rates directly, as well as indirectly because economic inequality may be conducive to gender inequality, which is hypothesized to increase violence. This study goes beyond most prior research by using a large sample of heterogeneous countries and by using a composite measure of gender inequality constructed by the United Nations, which captures several aspects of the gendered nature of society. Moreover, examining the influences of societal level characteristics on homicide rates separately for male and female victimization is important because the mechanisms explaining the violence may be different.

\section{Gendered perspective on macro-level variations in violence}

Over 40 years ago, Freda Adler (1975) and Rita Simons (1975) predicted that with increased gender equality, female rates of offending would start to resemble male rates. They argued that different role expectations for men and women, sex differences in socialization, application of social control and access to illegal opportunities were the primary causes for men's disproportionate offending rates. Although women have still not reached the economic and political power of men, the relative status of women has generally improved in recent decades. The gender gap in serious offending has decreased over time; this reduction is, however, due to a decrease in male offending, not in an increase in female offending (Lauritsen, Heimer \& Lynch 2009).

While traditional criminological theories generally do not focus on gender (as a social construct), some of the major theorists have acknowledged that instead of gender equality increasing female offending, it might narrow the gender gap by reducing male offending. In the late 1960s, Wolfgang and Ferracuti (1967) argued that "instead of females becoming more like males, males have increasingly taken on some of the roles and attributes formerly assigned mostly to females” (p. 259). Messner and Rosenfeld (2007) noted that men's greater engagement within the family would reduce their exposure to anomic pressure and thus lower the overall rates of crime. Others have similarly suggested that the increased presence of women in public life, which is associated with gender equality, may be associated with a civilizing process by reducing tolerance for violence (Lauritsen \& Heimer 2008).

A major theoretical advancement in criminology was introduced by Messerschmidt (1993) in Masculinities and Crime, in which he focused on the gendered nature of crime committed by men. Messerschmidt (1993) argued that some men commonly use crime and violence because it is intertwined with the social construction of masculinities (also see Connell 1995; Kimmel \& Mahler 2003).

\subsection{Social construction of masculinities}

From a constructionist perspective, a distinction is made between biological sex and socially constructed gendered behavior (Connell 1995, 2000; Kimmel \& Messner 2001; Messerschmidt 1993). Masculinity and femininity are created in social interactions within gendered stratified societies and become institutionalized and experienced as objective 
or natural. At the same time, gender is used to legitimize and reinforce the structure of stratification (Berger \& Luckmann 1966). Through socialization, men and women learn how to 'do' or perform gender; they learn what behaviors and attributes are appropriate and expected (West \& Zimmerman 1987).

Men are, on average, almost universally conferred a higher social status than women. Among men, masculinity is commonly used to rank the status of men. Men who do not behave manly are seen as inferior to men who perform the part (Kimmel \& Messner 2001). While collective cultural ideas about masculinity are specific to the society where they are created, competitive individualism, assertiveness and the capacity for violence tend to be almost universally associated with masculinity (Connell 1995; Messerschmidt 1993). Male-dominated societies are more likely than gender equal societies to value exaggerated ideas about masculinity (or 'hegemonic' masculinities) (Connell 2000). Beliefs concerning what constitutes a 'real man' may aggravate conflicts, thus escalating aggression (Holter 1995), resulting in high rates of violence in male-dominated societies.

As the family is the primary institution for the production and reproduction of polarized gender norms, individuals who grow up in societies where both the father and the mother participate in the work force, with similar professions, and both exhibit a close, ongoing relationship with their children, are likely to develop less stereotyped gender attitudes than men in more gender societies (Adams \& Coltrane 2004). Thus, men in more gender equal societies are likely to be able to back away from aggressive situations without it affecting their sense of manhood, they may have more diverse ways of enacting manhood than men in more gender-stratified societies.

\subsection{Prior research on the link between gender inequality and violence}

Neapolitan (1994) noted that Latin American countries have had on average higher homicide rates than other parts of the world, which he contributed to a 'macho' culture that is conducive to violence. He argued that "being brave, fearless, and never backing down" was central to masculinity in Latin America (p. 5). Neapolitan (1994) only included a 'dummy' variable for Latin American countries which he found to be the strongest predictor of high homicide rates. Using a larger sample of countries and controlling for additional variables (such as alcohol consumption), a dummy variable for Latin American countries was not significantly associated with homicide rates in a study conducted by Chon (2011).

Several studies have included a measure of female work participation or economic activities in their analysis of cross-national homicide rates (not disaggregated by the victim's sex). This has usually been done under the framework of lifestyle theories (i.e. routine activities theories) (Cohen \& Felson 1979) that maintain that households with working mothers will result in less guardianship of the family, and thus increased crime rates. Looking separately at rates of female and male homicide victimization, and examining 18 developed countries, Gartner (1990) found that from 1960 to 1980, female homicide rates were higher in countries with high female work participation. In that study, female labor force participation had no impact on male homicide victimization. Chon 
(2013a) found that gender equality in education and political power was associated with low female homicide rates. That relationship, however, disappeared when accounting for income inequality, human development and other similar measures. Stamatel (2014) examined female homicide victimization across 33 European countries and found that female labor participation was not related to female homicide rates, but high adolescent fertility rates were associated with lower female homicides and divorce rates associated with higher female homicide rates.

Research has also examined the cross-national relationship between gender inequality and non-lethal violence against women. Chon (2013b) as well as Austin and Kim (2000) found that measures of gender equality were associated with increased official rates of sexual violence. However, not only is the underestimation of sexual violence in official (police) data well known but also the results from cross-national studies focusing on the link between gender inequality and sexual violence are biased. Recording and reporting practices generally differ between countries (van Dijk 2011), and women in male-dominated societies are less likely to report their victimization to the police than women in more gender-equal societies. Thus, gender equality may be associated with increased willingness of women to report sexual violence, but not the actual prevalence of violence.

Yodanis (2004) used the International Crime Victimization Survey and reported that sexual violence tends to be more frequent in countries where women's status is low. Likewise, comparing 40 diverse countries, Kaya and Cook (2010) found that, net of several structural and cultural factors, countries with higher formal education of women and high female labor force participation in non-agricultural sectors had lower rates of physical violence against women by intimate partners. Research examining the link between gender inequality and female homicide victimization in the United States has also reported mixed results (for reviews see Pridemore \& Freilich 2005; Vieraitis, Britto \& Kovandzic 2007; Whaley \& Messner 2002; Titterington 2006).

Thus, the findings from prior studies have been mixed; either concluding that female status in society is associated with increased lethal violence (Neumayer 2003), decreased (Savage, Bennett \& Danner 2008), that the relationship depends on the source of information about homicide rates (Howard \& Smith 2005), or that it has no impact on homicide rates (Lee \& Shihadeh 1998).

\section{Income inequality and violence and the link to gender inequality}

Income inequality has been a consistent predictor of high homicide rates in a nation (for reviews, see Koeppel, Rhineberger-Dunn \& Mack 2015; Nivette 2011; LaFree 1999). While the intermediate processes between income inequality and violence are rarely empirically examined (Chamlin \& Cochran 2006), the theoretical explanations can be drawn from a wide range of perspectives. The relative deprivation framework theorizes that economic inequality is harmful because poverty is experienced within a certain sociocultural context (Runciman 1966). Poverty is particularly harmful in high-income countries because of the social stigma attached to being poor. Poor individuals in eco- 
nomically stratified societies may be "sensitive to being regarded as inferior and violence is frequently used as a consequence of feeling disrespected" (Wilkinson 2005, 151). Income, relative to the income of others, is a marker for overall social status and worth (Runciman 1966; Wilkinson 2005). Income inequality thus leads to frustration, anger and hostile social relations, which in turn lead to violence (Blau \& Blau 1982).

In nearly all societies, men have traditionally been the primary breadwinners and, thus, economic inequality is assumed to have a stronger impact on men than on women, and in particular impact social relations among men (Wilkinson 2005). Men adopt exaggerated masculine attitudes and behaviors to deal with feeling disrespected and humiliated, which is often felt by poor people in economically stratified societies (Currie 1997; Messerschmidt 1993; Wilkinson 2005). Economically stratified societies not only have higher rates of violence but also high male mortality rates related to risky behavior, such as accidents and alcohol and drug abuse. Wilkinson (2005) attributes high male mortality rates to the construction of masculinity in a "culture of inequality that is not only more violent and aggressive, but also more macho" (p. 219).

Men who feel subordinated in economically stratified societies may, however, try to repair their sense of selfhood by demonstrating their superiority over women. Income inequality may therefore also be linked to mistreatment of women. Cross-national comparisons have revealed that women tend to lack power in economically stratified societies (Mandel \& Semyonov 2005; Blau \& Kahn 1994).

Although cultural explanations (Wolfgang \& Ferracuti 1967) for regional differences in violence have been seen by some as competing with structural theories (such as the theory of relative deprivation) (e.g., Kornhauser 1978), these theories also perceive poverty and inequality as a source of violent behavior but through the formation of (sub)cultural values and norms. The subcultural argument is, in short, that there are groups within society whose members frequently use violence because they embrace "values and norms that support, legitimize, and encourage violence" in certain situations (Bernburg \& Thorlindsson 2005, 457). Central to the subcultural perspective is the idea that violent and aggressive behavior converges with notions regarding masculine ideals (Wolfgang \& Ferracuti 1967, 260).

Hence, one assumption of the main theories used to explain the relationship between economic inequality and rates of violence is that it intersects with expressions of masculinities. In economically stratified countries, income will determine the resources available for men to achieve masculinity. In many societies race and class will be particularly relevant in this respect (Messerschmidt 1993). Well-off men will be able to demonstrate manliness by providing for their families (or do other things that visually represent material success) but poor men may feel the need to engage in dangerous and sometimes lethal behaviours to protect their masculine identity.

\section{Hypotheses}

Given the integrated theoretical framework discussed above, I test the model depicted in figure 1. In sum, I expect levels of both income- and gender inequality to be associated 
with high rates of female and male homicide victimization. If income inequality is particularly harmful to the social relations among men, we should see a stronger relationship between income inequality and male homicide victimization than between income inequality and rates of female victimization. I also hypothesize that levels of income inequality will be associated with gender inequality, which will partly explain the relationship between income inequality and homicide rates. More specifically, I formulate the hypotheses as follows:

H1: There is a positive association between gender inequality and rates of female and male homicide victimization.

H2: There is a positive association between income inequality and rates of female and male homicide victimization.

$H 2 b$ : The relationship is stronger for male homicide victimization. H3: There is an indirect relationship between income inequality and female and male homicide victimization through gender inequality (a part of the relationship between economic inequality and homicide rates is mediated through gender inequality).

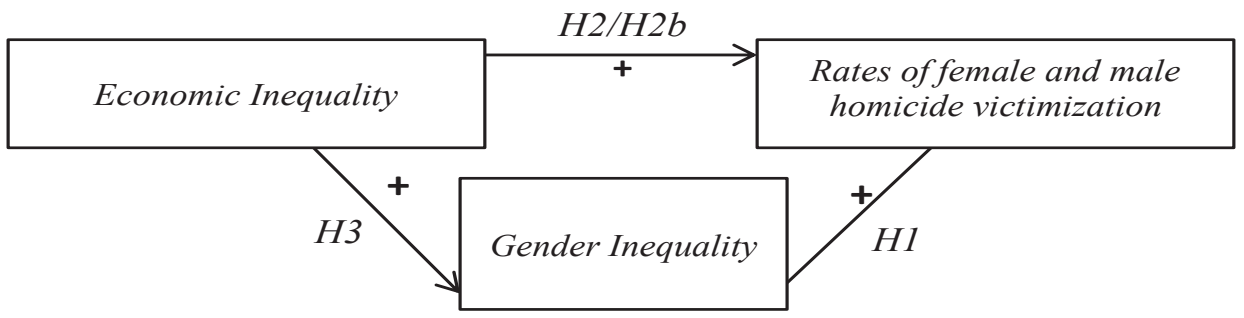

Figure 1. Hypothesized Model

\section{Methodology}

\subsection{Sample/data}

The analysis is based on information from various sources, including the World Health Organization (WHO), United Nations (UN), and the World Bank. The WHO's Global Health Estimates (GHE) database provides information about homicides for 172 countries. However, information on all variables included in the following models was only available for 129 countries. I detected two outliers (Qatar and United Arab Emirates) that were deleted from the analysis resulting in a final sample size of 127 countries ${ }^{1}$. This sample is larger than those used in most cross-national studies to date. The sample includes approximately an equal number of highly developed countries, medium-developed countries and countries with low development (according to the classification on the human development index from the UN). 


\subsection{Measures}

Homicide is considered the most reliable cross-national measure of violence, as variations in legal definitions, reporting, and recording practices in different countries are likely to influence other measures of violence (LaFree 1999). Scholars have also noted that WHO provides the most reliable and comparable information on lethal violence between countries (Rogers \& Pridemore 2013). I use information from WHO's GHE database about deaths caused by interpersonal violence to measure the rates of female and male homicide victimization (the number of female homicide victims per 100,000 females in a country, and the same for men). I use the average of the information given for the years 2008 and 2012. The two measures of homicide rates were positively skewed and, thus, I used a natural log transformation. Descriptive statistics are shown in table 1.

The Gender Inequality Index (GII) constructed by the United Nations Development Programme captures the gendered nature of society well. First, the composite measure includes the reproductive health of women (maternal mortality and adolescent fertility), which reflects a traditional ideology of women's primary role as mothers. Second, seats in national parliament (the proportion of seats held by women in a lower or single house or an upper house or senate expressed as the percentage of total seats) and women's education (the percentage of the female population aged 25 years and older with secondary education) are used as indicators of women's empowerment. Finally, the proportion of a country's working age women's population that engages in the labor market by either working or actively looking for work is used as women's labor market status. The most recent measure available is used, which includes information from 2006 to 2012.

The criterion validity of the GII was tested by examining the correlation between the GII and several measures of gender norms from the World Value Survey (2005-2006 wave).

- When jobs are scarce, men should have more of a right to a job than women

- On the whole, men make better political leaders than women do

- A university education is more important for a boy than for a girl

- On the whole, men make better business executives than women do

The percentage of respondents agreeing with the four statements has a strong bivariate correlation with the GII (person's r ranges from 0.65 to $0.67, \mathrm{p}<0.01 \mathrm{~N}=51$ ) indicating that the measure captures not only structural gender inequality but also gendered norms. The questions all have a stronger bivariate correlation with the GII than with separate measures of women's political power, women's educational attainment and women's job participation. The only exception is a bivariate correlation between the statement "when jobs are scarce ..." and women's job participation which has the strongest correlation ( $\mathrm{r}$ $=-0.72, \mathrm{p}<0.01)$. Further, in a recent research the GII was associated with variations of acceptability of partner violence between 51 societies (Gerrero, Rodriguez \& Torres 2016) as well associated with variations in physical aggression between married partner in 31 countries (Ebbeler, Grau \& Banse 2017). 
Several international measures of gender inequality are available. In addition to the GII, research also use the Gender Equity Index (GEI) conducted by the Social Watch, the Gender Empowerment (GE) measure by the UN, or the Social Institutions and Gender Index (SIGI) created by the OECD Development Centre. The GEI and the GE are similar to the GII but include fewer items, and thus have less content validity (Singleton and Straits 2010). The SIGI measure captures multiple aspects of gender inequality in a nation, including violence against women (see The OECD development centre's social institutions and gender index n.d.). The SIGI measure is therefore not appropriate as it measures the same construct it should be predicting (the bivariate correlation between the SIGI and the GII measure in 88 countries that have available measure is strong, $\mathrm{r}=0.70, \mathrm{p}<0.01)$.

Income inequality is measured using the Gini coefficient where a value of 0 represents absolute equality and a value of 100 represents absolute inequality. I used the average score for the years 2000 to 2010 from the World Bank. The World Bank did not have information on income inequality for 11 of the 127 countries in the sample. To prevent losing countries from the sample, I used information from the Solt's Standardized World Income Inequality Database for 2007 for these 11 countries (see Teorell et al. 2013) 2 .

The selection of control variables is based on findings from prior studies. To isolate the hypothesized relationships, I control for other well-known covariates of cross-national homicide rates. First, I control for the nation's per capita gross domestic product (GDP) in US\$. GDP, which is considered an indicator of the overall economic prosperity of a country, is commonly found to be negatively related to homicide rates (Agha 2009; Altheimer 2008, 2013; Barber 2009; Pridemore 2011). The measure comes from the World Bank. I use the average score for the years 2008 to 2012. In the analyses in tables 2 through 4, the GDP measure is multiplied with 10.000. This is done to prevent multiple decimals. The raw score is shown in table 1.

Fractionalization reflects the likelihood that two randomly selected people in a given country will share certain characteristics; the higher the number is, the less likely that the two people share that characteristic. Consistent with prior studies (Chu \& Tusalem 2013; Altheimer 2013), I control for ethnic fractionalization, which involves a combination of racial and linguistic characteristics. Ethnic fractionalization is held to increase cultural conflicts and reduce informal social control (Blau 1977; Blau \& Blau 1982). The original source of information is derived from Alesina et al. (Teorell et al. 2013) and represents the year 2009.

Urbanized countries are expected to have higher rates of homicides than countries with low population density and thus I control for percentage of population living in urban areas (Pratt \& Godsey 2003). Urbanization is also considered to be a measure of level of modernization in a society (Inglehart \& Norris 2003). The world Bank provided the information for the year 2008. Consistent with previous cross-national research (Chu \& Tusalem 2013; Pratt \& Godsey 2003; Rogers \& Pridemore 2013), I also control for the adult male to female ratio in the population from the World Bank in the year 2008. This measure was constructed by dividing the male population by the female 
population. A value of 1 represents a population that has equal number of males and females. Low ratio of males to females is theorized to increase family disruption, which research indicates leads to crime and violence (Barber 2009; Messner \& Sampson 1991).

Finally, recent studies (Chon 2011; Pridemore 2002; Rossow 2001; Wolf, Gray \& Fazel 2013) have reported that the alcohol consumption in a country is related to increased rates of homicide. Thus, I use a three-year average (2008-2010) of the recorded amount of alcohol consumed (15+ years) in liters of pure alcohol per capita from $\mathrm{WHO}^{3}$.

\subsection{Analytical strategy}

I use Ordinary Least Square (OLS) regression to test the hypotheses. All models below met the assumptions of OLS linear regression. For example, I examined the presence of heteroscedasticity both visually and by formally testing the assumption. Using the Breusch-Pagan/Cook-Weisberg test, I was able to verify constant errors in all of the models (e.g. results from model 1 in table $2: \chi(1)=0.43$, Prob $>\chi 22=0.51$ ). I evaluated multicollinearity by first looking at the bivariate correlations between the independent variables. In this sample, the strongest bivariate correlation is between GII (gender inequality) and GDP $(\mathrm{r}=-0.73, \mathrm{p}<0.01)$. I also calculated the variation inflation factor (VIF) for all independent variables, the highest VIF was 4.87 for GII. Although several researchers and most statistical textbooks consider VIF exceeding 10 to merit concern (Myers 1990, 369; Kutner, Nachtsheim \& Neter 2004, 409), others have concluded that a model with VIF above 4 should be viewed with some caution (Pratt \& Godsey 2002). I analyzed the data after dropping GDP from the models as well as running all models separately for high and low GDP countries without it substantially changing other findings.

\section{Findings}

Table 1 shows the bivariate relationships between all variables included in the analysis as well as descriptive statistics. In the correlation matrix, the homicide variables are logged, but the descriptive statistics are presented for the raw scores. The highest average rates of female homicide victimization were in Lesotho (17.20 per 100,000 female population). El Salvador had the highest male homicide victimization (131.60 per 100,000 male population). The lowest female homicide victimization was reported in Ireland, but Japan had the lowest male homicide victimization. The gender inequality index ranges from 0.05 (in Sweden and in the Netherlands) to 0.74 (in Chad). The highest score on the Gini coefficient measuring income inequality is for Namibia and South Africa (63.90). The lowest score was observed in Norway (24.63) indicating a relatively small gap between rich and poor people in that country.

There is a strong bivariate correlation between female and male homicide victimization $(r=0.92, p<0.01)$. Nations that have high rates of lethal violence against women also have high rates of lethal violence against men. Rates of female and male homicide victimization have a moderately strong bivariate correlation with both gender inequality and income inequality.

I report the unstandardized as well as the standardized coefficients in tables 2 through 4. Whereas the unstandardized coefficient is dependent on the measures of each vari- 
able, the standardized coefficient represents the average standard deviation change in the dependent variable for each standard deviation increase in the independent variable- and thus gives some indication of the relative impact of each predictor within the same model. I begin by examining the relationship between gender inequality and levels of female and male homicide victimization in models 1 and 2 (in table 2); testing hypothesis 1.

Table 1. Correlation matrix and descriptive statistics

\begin{tabular}{|c|c|c|c|c|c|c|c|c|c|c|}
\hline & & 1 & 2 & 3 & 4 & 5 & 6 & 7 & 8 & 9 \\
\hline 1 & $\begin{array}{l}\text { Female homicide victimiza- } \\
\text { tion rates }(\ln )\end{array}$ & 1 & & & & & & & & \\
\hline 2 & $\begin{array}{l}\text { Male homicide victimization } \\
\text { rates }(\ln )\end{array}$ & $.92 * *$ & 1 & & & & & & & \\
\hline 3 & Gender inequality index & $.72^{* *}$ & $.75^{* *}$ & 1 & & & & & & \\
\hline 4 & Income inequality & $.62^{* *}$ & $.71^{* *}$ & $.51 * *$ & 1 & & & & & \\
\hline 5 & GDP & $-.63^{* *}$ & $-.66 * *$ & $-.73 * *$ & $-.45 * *$ & 1 & & & & \\
\hline 6 & Ethnic fractionalization & $.52^{* *}$ & $.51^{* *}$ & $.65^{* *}$ & $.30 * *$ & $-.44^{* *}$ & 1 & & & \\
\hline 7 & $\%$ urban population & $-.46 * *$ & $-.43^{* *}$ & $-.66 * *$ & $-.19 *$ & $.61^{* *}$ & $-.41 * *$ & 1 & & \\
\hline 8 & Male to female ratio & $-.36^{* *}$ & $-.39 * *$ & -.12 & $-.30 * *$ & $.22^{*}$ & -.15 & .10 & 1 & \\
\hline \multirow[t]{5}{*}{9} & Alcohol consumption & $-.19 *$ & $-.26 * *$ & $-.62^{* *}$ & $-.23 * *$ & $.42^{* *}$ & $-.34 * *$ & $.41^{* *}$ & -.10 & 1 \\
\hline & Mean & 3.80 & 17.00 & 0.39 & 39.10 & 13900.8 & 0.44 & 56.00 & 0.99 & 7.03 \\
\hline & SD & 3.79 & 25.53 & 0.20 & 8.92 & 20148.5 & 0.26 & 22.85 & 0.05 & 4.22 \\
\hline & Min & 0.25 & 0.42 & 0.05 & 24.63 & 219.9 & 0.00 & 10.14 & 0.86 & 0.10 \\
\hline & Max & 17.20 & 131.60 & 0.74 & 63.90 & 107165.8 & 0.93 & 100 & 1.22 & 17.50 \\
\hline
\end{tabular}

$*_{\mathrm{p}}<0.05 \quad *^{*} \mathrm{p}<0.01 \quad \mathrm{~N}=127$

The results in table 2 show that there is a strong positive association between gender inequality and rates of lethal violence against women. Model 1 indicates that for one standard deviation increase in gender inequality, female homicide victimization increases on average by 0.64 standard deviation $(\beta=0.64, \mathrm{p}<0.01)$, net of other variables in the model. High levels of gender inequality in a nation are also associated with high rates of lethal violence against men $(\beta=0.63, \mathrm{p}<0.01)$. It is important to note that the standardized coefficients are not comparable between models, and in fact the unstandardized coefficient for the effects of gender inequality is larger in the model predicting male victimization. Multivariate multiple regression (regression with more than one outcome ${ }^{4}$ was used to formally test the null hypothesis that the coefficient for gender inequality with female victimization as an outcome was equal to the coefficient for gender inequality with male victimization as an outcome. The result from that test $(\mathrm{F}(1,119)=1.80$, $\mathrm{P}=0.182$ ) shows that the relationship between gender inequality and female homicide victimization is not significantly different from the relationship between gender inequality and male victimization.

In models 1 and 2 (in table 2) I also examine the direct relationship between income inequality and homicide rates (while controlling for GII), thus testing hypothesis 2 . In- 
come inequality has a statistically significant relationship with both female $\beta=0.25$, $\mathrm{p}<0.01)$ and male homicide victimization $(\beta=0.33, \mathrm{p}<0.01)$. Using the same test described above, the findings show that income inequality has a statistically significantly stronger relationship with male homicide victimization than female victimization ( $\mathrm{F}(1$, 119) $=13.19, \mathrm{p}<0.01)$, thus supporting hypothesis $2 \mathrm{~b}$.

While the relationship between GDP in a country and homicide victimization is in the direction expected, only the association with male victimization is statistically significant $(\beta=-0.15, \mathrm{P}<0.05)$. Neither ethnic fractionalization nor urbanization have a significant relationship with homicide victimization. The ratio males to females in the population is negatively associated with both female $(\beta=-0.13, \mathrm{P}<0.01)$ and male $(\beta$ $=-0.16, \mathrm{P}<0.01)$ homicide rates. Although the direction of this relationship may seem counterintuitive (as men are more likely to offend than women), it is consistent with previous research. It has been proposed that the relationship may be causally reversed; that countries with high male homicide rates have lower ratio of male to female population (Savolainen 2000), which would, however, only explain higher male victimization. Others have suggested that a low ratio of males to females results in family disruption, which research indicates increases crime and violence (Barber 2009; Messner \& Sampson 1991). Finally, alcohol consumption is associated with high levels of lethal violence against women $(\beta=0.33, \mathrm{p}<0.01)$ and high male victimization $(\beta=0.23, \mathrm{p}<0.01)$. The independent variables in the models explain a substantial part of the variation of male homicide victimization in this sample (adj. $\mathrm{R} 2=0.78)$, as well as a large part of the variance of female's victimization (adj. $\mathrm{R} 2=0.70)$.

Table 2. OLS regression estimates predicting rates of homicide victimization (logged) and gender inequality

\begin{tabular}{|c|c|c|c|c|c|c|}
\hline & \multicolumn{3}{|c|}{$\begin{array}{l}\text { Female victimization } \\
\text { Model } 1\end{array}$} & \multicolumn{3}{|c|}{$\begin{array}{l}\text { Male victimization } \\
\text { Model } 2\end{array}$} \\
\hline & B & SE & $\beta$ & b & $\mathrm{Se}$ & $\beta$ \\
\hline Constant & .84 & & & 2.50 & & \\
\hline Gender inequality index & 3.31 & 0.53 & $.64^{* *}$ & 4.21 & .63 & $.63^{* *}$ \\
\hline Income inequality & .03 & .01 & $.25^{* *}$ & .05 & .01 & $.33^{* *}$ \\
\hline \multicolumn{7}{|l|}{ Controls: } \\
\hline GDP & -.01 & .00 & -.13 & -.01 & .00 & $-.15^{*}$ \\
\hline Ethnic fractionalization & .22 & .26 & .06 & .16 & .29 & .03 \\
\hline$\%$ Urban population & -.00 & .00 & -.01 & .00 & .00 & .07 \\
\hline Male to female Ratio & -2.96 & 1.18 & $-.13 * *$ & -4.70 & 1.34 & $-.16^{* *}$ \\
\hline Alcohol consupmtion & .08 & .02 & $.33 * *$ & .07 & .02 & $.23^{* *}$ \\
\hline Adj. R2 F-value & \multirow{2}{*}{\multicolumn{3}{|c|}{127}} & \multirow{2}{*}{\multicolumn{3}{|c|}{.78}} \\
\hline $\mathbf{N}$ & & & & & & \\
\hline
\end{tabular}

$b=$ unstandardized coefficient $\quad S E=$ standard error $\quad \beta=$ standardized coefficient

${ }^{*} \mathrm{p}<.05{ }^{* *} \mathrm{p}<.01$ 
Table 3. OLS regression estimates predicting rates of homicide victimization (logged) and gender inequality

\begin{tabular}{|c|c|c|c|c|c|c|c|c|c|}
\hline & \multicolumn{3}{|c|}{$\begin{array}{l}\text { Female victimization } \\
\text { Model } 1\end{array}$} & \multicolumn{3}{|c|}{$\begin{array}{l}\text { Male victimization } \\
\text { Model } 2\end{array}$} & \multicolumn{3}{|c|}{$\begin{array}{l}\text { Gender Inequality Index } \\
\text { Model } 3\end{array}$} \\
\hline & B & SE & $\beta$ & B & SE & $\beta$ & $b$ & Se & $\beta$ \\
\hline Constant & 1.41 & & & 3.23 & & & .17 & & \\
\hline Gender inequality index & --- & --- & --- & --- & --- & --- & --- & --- & --- \\
\hline Income inequality & .04 & .01 & $.39 * *$ & .07 & .01 & $.46^{* *}$ & .01 & .00 & $.21^{* *}$ \\
\hline \multicolumn{10}{|l|}{ Controls: } \\
\hline GDP & -.01 & .00 & $-.30^{* *}$ & -.02 & .00 & $-.31^{* *}$ & -.01 & .00 & $-.26 * *$ \\
\hline Ethnic fractionalization & .96 & .25 & $.24 * *$ & 1.09 & .30 & $.21^{* *}$ & .22 & .03 & $.29 * *$ \\
\hline$\%$ Urban population & -.01 & .00 & $-.16^{*}$ & -.00 & .00 & -.08 & -.00 & .00 & $-.24 * *$ \\
\hline Male to female Ratio & -2.39 & 12420 & -.11 & -3.97 & 20455 & $-.14 *$ & .17 & .19 & .04 \\
\hline Alcohol consupmtion & .04 & .02 & $.16^{*}$ & .02 & .02 & $.07^{* *}$ & -.01 & .00 & $.26 * *$ \\
\hline Adj. R2 F-value & \multicolumn{3}{|c|}{$2234.85^{* *}$} & \multirow[t]{2}{*}{.69} & \multicolumn{2}{|c|}{$48.73^{* *}$} & \multicolumn{3}{|c|}{$.78 \quad 77.42^{* *}$} \\
\hline $\mathbf{N}$ & \multicolumn{3}{|c|}{127} & & \multicolumn{2}{|l|}{127} & \multicolumn{3}{|c|}{127} \\
\hline
\end{tabular}

$\mathrm{b}=$ unstandardized coefficient $\mathrm{SE}=$ standard error $\quad \beta=$ standardized coefficient

$* p<.05 * * p<.01$

Hypothesis 3 states that income inequality is indirectly associated with homicide rates through gender inequality; that a part of the relationship between income inequality and homicide rates is mediated through gender inequality. Income inequality must be significantly associated with gender inequality to draw conclusions about mediation. The results in model 3 , in table 3 , show that the relationship between income inequality and gender inequality is positive and statistically significant $(\beta=0.21, \mathrm{p}<0.01)$. Table 3 also shows the direct association between income inequality and homicide rates before controlling for gender inequality. For female victimization, the standardized coefficient for income inequality decreased from $0.39 * *$ to $0.25^{* *}$ when controlling for gender inequality. Thus, about $36 \%(0.25-0.39 / 0.39)$ of the relationship between income inequality and female victimization is mediated through gender inequality. About $28 \%$ of the relationship between income inequality and male victimization is mediated through gender inequality (0.33-0.46/0.46).

I generated bootstrap confidence intervals (based on 10,000 samples calculated with the Process macro in SPSS), a method recommended to by Hayes (2013) to test if the mediation is statistically significant. The bootstrap confidence intervals for the indirect effects were both above zero ( 0.0072 to 0.02 for female victimization and 0.0082 to 0.0256 for male's victimization) and thus statistically significant. In other words, income inequality not only has a direct effect on homicide victimization but also indirect effects through its effects on gender inequality. 


\subsection{Sensitivity analysis}

I conducted additional analysis to ensure that the results in the tables above support the hypotheses. As I was only able to get a two-year average for homicide rates by the victim's gender, I also conducted the analysis predicting the average homicide rates from 2008 to 2015. Using additional years should ensure the reliability of the dependent variable (as there may be some fluctuation in homicide rates). The results in table 4 are essentially the same as shown in table 2, thus giving additional support to the proposed hypotheses.

Table 4. OLS regression estimates predicting rates of homicide victimization (logged) and gender inequality

\begin{tabular}{|c|c|c|c|}
\hline & \multicolumn{3}{|c|}{$\begin{array}{c}\text { Average Homicide Rates 2008-2015 } \\
\text { Model } 1\end{array}$} \\
\hline & B & SE & $\beta$ \\
\hline Constant & 2.50 & & \\
\hline Gender inequality index & 4.21 & 0.63 & $.63^{* *}$ \\
\hline Income inequality & .05 & .01 & $.33 * *$ \\
\hline \multicolumn{4}{|l|}{ Controls: } \\
\hline GDP & -.01 & .00 & $-.15^{*}$ \\
\hline Ethnic fractionalization & .16 & .29 & .03 \\
\hline$\%$ Urban population & -.00 & .00 & -.07 \\
\hline Male to female Ratio & -4.70 & 1.34 & $-.16^{* *}$ \\
\hline Alcohol consupmtion & .00 & .0 & .07 \\
\hline Adj. R2 F-value & \multicolumn{3}{|c|}{.78} \\
\hline N & \multicolumn{3}{|c|}{127} \\
\hline
\end{tabular}

$\mathrm{b}=$ unstandardized coefficient $\mathrm{SE}=$ standard error $\quad \beta=$ standardized coefficient ${ }^{*} \mathrm{p}<.05{ }^{* *} \mathrm{p}<.01$

\section{Discussion}

The current study examined the relationship that income and gender inequality have with lethal violence against both women and men. The results show that both types of inequalities are associated with increased rates of lethal violence within a nation.

The theory of relative deprivation (Blau \& Blau 1982; Runciman 1966) implies that economic inequality leads to frustration, anger and hopelessness, which in turn lead to violence. Economic stratification is associated with power struggles and has been assumed to increase other social inequalities, such as inequalities between men and women. Economically stratified societies are presumed to be more male-dominated than countries with less income inequality (Wilkinson 2005). High levels of gender inequality have also been theorized to increase violence. Feminist theories (e.g., Brownmiller 1975) 
claim that violence against women or threat of such violence is used to keep women subordinated in patriarchal societies (Hunnicutt 2009; Yodanis 2004; Whaley 2001).

There is less empirical and theoretical work that addresses how gender inequality potentially influences male victimization rates. However, Connell's $(1995,2002)$ and Messerschmidt's (1993) work on masculinities and gender regimes has been key in understanding male gender identities and practices in different societies. Gender-stratified societies tend to value traditional masculinity, where toughness and aggression is emphasized. These values sometimes lead to violence against women, but also, and in particular, violence against other men (DeKeseredy \& Schwartz 2015).

While several cross-national studies have examined the relationship between income inequality and violence, there is limited research on the link between income inequality and gender inequality (see however, Inglehart \& Norris 2003). Research focusing on the link between gender inequality and violence is also rare, and most of existing studies focus exclusively on violence against women. Accordingly, the present study examined the interconnected influences of income- and gender inequality on both female and male homicide victimization. Specifically, I tested the hypotheses that income inequality is associated with high rates of homicide victimization, and that a part of that relationship is mediated through gender inequality. I also tested if income inequality had a stronger correlation with male homicide victimization than female homicide victimization. The present study, using a sample of 127 heterogeneous countries, supports these hypotheses.

First, my results indicate that economically stratified societies tend to be male-dominated; there is a cross-national association between income inequality and gender inequality (see H3 in figure 1). This study supports previous research, demonstrating that income inequality is associated with high levels of lethal violence (see H2 in figure 1). The study indicates, however, that income inequality has a different impact on male and female homicide victimization (see $\mathrm{H} 2 \mathrm{~b}$ in figure 1). Income inequality is strongly related to male victimization, but has a somewhat weaker association with female homicide rates, which is in line with previous findings (Gartner 1990; Savolainen 2000). While poverty is likely equally harmful to men and women, my results support the proposition that low economic status impacts men's self-worth and their masculine identity; that it increases frustration and hostility among men, more than it does among men and women (Wilkinson 2005; Messerschmidt 1993).

Feminist theorists (e.g., Brownmiller 1975) have long argued that violence against women reflect the devaluation of women's lives. Gender equality is thus expected to be associated with a cultural ideology where women's autonomy is respected and thus with decreased violence against women. Gender equality has, however, also been predicted to be associated with increased violence against women. Scholars (Gartner 1990; Gartner, Barker \& Pampel 1990) have noted that as the lifestyles of women start to resemble the lifestyles of men, women's victimization may increase, particularly from violence committed by strangers, or perpetrators outside the family. But data from the UN demonstrate that worldwide, an average of 79 percent of women who are killed are killed by an intimate partner (UNOCD 2013). 
In 2013a (and again in 2016) Chon published a paper with the title A Spurious Relationship of Gender Equality with Female Homicide Victimization where he concluded that after accounting for gross domestic product, income inequality and ethnic heterogeneity, there is in no relationship between gender equality and lethal violence against women. The main difference between the current research and the one published by Chon (2013a) is how gender inequality is measured. Chon's measures the relative status of women (that becomes insignificant after adding the control variables) with a composite measure of women's educational status and political empowerment, but the current study uses the gender inequality index (GII) conducted by the United Nations. The GII includes women's educational status, their political engagement, women's job participation as well as women's reproductive health (maternal mortality and adolescent fertility), which reflects a traditional ideology of women's primary role as mothers. In the current study, additional steps were taken to specifically test the validity of the GII (e.g. looking at the relationship with gender norms within a nation). Gender inequality is reflected in multiple complex ways and thus not captured solely by women's education or their political participation (Inglehart \& Norris 2003). My findings strongly indicate that the relationship between gender inequality and violence against women is indeed not spurious. The current research, using a larger sample than most previous cross-national studies, as well as a more inclusive measure of gender inequality, shows that gender inequality is in fact associated with increased violence against women. The findings reported in this study also indicate that gender inequality increases violence against men (see H1 in figure 1).

There are, however, limitations to the present research that should be noted. The findings are based on cross-sectional designs and thus do not enable causal inferences. Strong theoretical and empirical literature already indicates that income inequality increases violence and not vice versa. As has been discussed, there is less support in the literature for the causal effects of gender inequality on violence. I have argued that, for several reasons, gender inequality exacerbates conflicts and leads to high rates of violence. However, the question remains: Are gender-equal countries less violent because of gender equality, or have women gained more power in countries that are more peaceful?

Additionally, although homicide is considered the most reliable measure of cross-national variations of serious violence, it is not without limitation. Some societies may have high rates of violence but have fewer people dying as a result of their injuries because of good health care (Lauritsen \& Heimer 2008). This finding would lead us to overestimate the relationship between gender inequality and violence as there tends to be less gender inequality in wealthier countries compared to poorer countries.

The theoretical argument presented in this study has focused on explaining violence committed by men against women as well as against other men. Yet, information regarding the gender gap in homicide offending was not available. Recent data from the United Nations show, however, that men represent 95 percent of those convicted of lethal violence worldwide (UNOCD 2013). Moreover, a cross-national study of homicide arrest rates reported that males had a much higher rate of homicide offending than females: 12.5 per 100,000 population for males compared to 1.1 for females (Agha 2009). The 
field would, however, benefit from future research disaggregating offending as well as victimization rates by sex.

There is a long-standing research literature demonstrating the harmful consequences of social and economic inequality. Specifically, inequality is associated with poor public health (Babones 2008; Spencer 2004) and depressed political engagement (Solt 2008). Thus, governmental measures to promote gender and income equality are important in democratic societies. The implications of the current study are that these measures can also be a step towards reducing violence committed against both men and women. The findings presented in this study also indicate that policies aimed at restricting alcohol consumption can potentially decrease serious violence. Nations with higher levels of alcohol consumption tend to have higher rates of lethal violence.

In sum, there has been little integration between the literature on gender and violence against women on the one hand and broader research on crime and violence on the other (Lauritsen \& Heimer 2008). This is unfortunate considering that, independent of the victim's sex, crime and violence are highly 'gendered' or masculine behaviors (Messerschmidt 1993). Although men may benefit from privileges gained from the subordination of women, the findings in the present study indicate that both men and women are harmed because of higher levels of violent victimization in male-dominated societies.

\section{Notes}

1 Several steps were taken to identify extreme cases with undue influence on the estimated parameters. I examined the leverage values, Cook's Distance, and DFFITS and DFBETAS for each case. This let me to drop Qatar and United Arab Emirates from the analysis. These two outliers had very high hat values (centered leverage), 0.29 and 0.25 respectively. A common recommendation is to use $(2 \mathrm{k}+2) / \mathrm{n}$ or $(3(\mathrm{k}+1) / \mathrm{n})$ as a cut-off point (Kutner et al. 2004). The hat-values for these two countries are much higher than the cut-off point using either formula. In these two countries, foreign workers with temporary residence status, of which most are men, make up a large part of the population resulting in extremely high ratio of male to female population. Most countries have about equal number of males and females, the average for the sample (excluding Qatar and United Arab Emirates) is 0.99 with a standard deviation of 0.05 . The male population in Qatar is however almost fourfold the female population, and almost threefold in United Arab Emirates.

2 I conducted the analysis using only those countries with a Gini coefficient available from the World Bank; the findings did not change. I also performed the analysis using the Quintile income ratio measure of inequality (the ratio of share of income of the richest 20 percent of the population to the share of the income of the poorest 20 percent) from the World Bank, and the findings remained substantially the same.

3 There is no clear consensus in the literature on what variables should be used as controls. Examples of control variables used by some researchers, but not in the current study, are infant mortality, percent of population consisting of young men, population density, levels of democracy and human development. I ran the analysis including these variables in the models (one at a time) and it did not influence the main results. Using additional variables in the final model would increase multicollinearity and thus result in unstable coefficients.

4 Multivariate multiple regression can be used to test if the coefficient for the same predictors is different for two (or more) conceptually related outcomes (see for example, Stevens 2009, 145-156). I used the mvreg command in STATA to conduct multivariate analysis, followed by the command: test[male homicide victimization] GII $=$ [female homicide victimization $]$ GII. 


\section{References}

Agha, S. (2009). "Structural Correlates of Female Homicide: A Cross-national Analysis", Journal of Criminal Justice 37(6), 576-585. doi:10.1016/j.jcrimjus.2009.09.006

Adams, M., and Coltrane, S. (2004). "Boys and Men in Families: The Domestic Production of Gender, Power and Privilege", in M.S. Kimmel, J.R. Hearn, and R.W. Connell (eds.), The Handbook of Studies on Men and Masculinities (pp. 230-248). Thousand Oaks, CA: Sage.

Adler, F. (1975). Sisters in Crime. New York, NY: McGraw-Hill.

Altheimer, I. (2008). "Social Support, Ethnic Heterogeneity, and Homicide: A Cross-national Approach", Journal of Criminal Justice 36(2), 103-114. doi: http:/ / dx.doi.org/10.1016/j.jcrimjus.2008.02.002

Altheimer, I. (2013). "Cultural Processes and Homicide Across Nations", International Journal of Offender Therapy and Comparative Criminology 57(7), 842-863. doi:10.1177/0306624X12438756

Austin, R.L., and Kim, Y.S. (2000). "A Cross-national Examination of the Relationship Between Gender Equality and Official Rape Rates", International Journal of Offender Therapy and Comparative Criminology 44(2), 204-221. doi:10.1177/0306624x00442006

Babones, S.J. (2008). "Income Inequality and Population Health: Correlation and Causality", Social Science \& Medicine 66(7), 1614-1626. doi:10.1016/j.socscimed.2007.12.012

Barbaret, R. (2014). Women, Crime, and Criminal Justice: A Global Enquiry. London, UK. and New York, NY: Routledge.

Barber, N. (2009). "Countries with Fewer Males have more Violent Crime: Marriage Markets and Mating Aggression”, Aggressive Behavior 35(1), 49-56. doi:10.1002/ab.20291

Berger, P.L., and Luckmann, T. (1966). The Social Construction of Reality. New York, NY: Anchor Books.

Bernburg, J.G., and Thorlindsson, T. (2005). "Violent Values, Conduct Norms, and Youth Aggression: A Multilevel Study in Iceland", The Sociological Quarterly 46(3), 457-478. doi:10.1111/j.15338525.2005.00022.x

Blau, F.D., and Kahn, L.M. (1994). "Rising Wage Inequality and the U.S. Gender Gap", The American Economic Review 84(2), 23-28. doi:10.2307/2117795

Blau, J.R., and Blau, P.M. (1982). "The Cost of Inequality: Metropolitan Structure and Violent Crime”, American Sociological Review 47(1), 114-129. doi:10.2307/2095046

Blau, P.M. (1977). "Inequality and Heterogeneity: A Primitive Theory of Social Structure", Social Forces 58(2), 677-683.

Brownmiller, S. (1975). Against our Will: Men, Women, and Rape. New York: Bantam Books.

Chamlin, M.B., and Cochran, J.K. (2006). "Economic Inequality, Legitimacy, and Cross-national Homicide Rates", Homicide Studies 10(4), 231-252. doi:10.1177/1088767906292642

Chesney-Lind, M. (2006). "Patriarchy, Crime, and Justice: Feminist Criminology in an era of Backlash", Feminist Criminology 1(1), 6-26. doi:10.1177/1557085105282893

Chon, D.S. (2011). "Contributing Factors for High Homicide Rate in Latin America: A Critical Test of Neapolitan's Regional Subculture of Violence Thesis" Journal of Family Violence 26(4), 299-307. doi:10.1007/s10896-011-9365-5

Chon, D.S. (2013a). "A Spurious Relationship of Gender Equality with Female Homicide Victimization: A Cross-national Analysis", Crime and Delinquency 63(3), 1-23. doi:10.1177/0011128713492497

Chon, D.S. (2013b). "Test of Impacts of Gender Equality and Economic Development on Sexual Violence", Journal of Family Violence 28(6), 603-610. doi:10.1007/s10896-013-9523-z

Chu, D.C., and Tusalem, R.F. (2013). "The Role of the State on Cross-National Homicide Rates", International Criminal Justice Review 23(3), 252-279. doi:10.1177/1057567713500790

Cohen, L.E., and Felson, M. (1979). "Social Change and Crime Rate Trends: A Routine Activity Approach", American Sociological Review 44(4), 588-608. doi:10.2307/2094589

Connell, R.W. (1995). Masculinities. Cambridge, UK: Polity Press.

Connell, R.W. (2000). The Men and the Boys. Cambridge, UK: Polity Press.

Connell, R.W. (2002). Gender. Cambridge, UK: Polity Press. 


\section{STJÓRNMÁL \& STJÓRNSÝSLA}

Currie, E. (1997). "Market, Crime and Community: Toward a Mid-Range Theory of Post-industrial Violence", Theoretical Criminology 1(2), 147-172. doi:10.1177/1362480697001002001

DeKeserdy, W.S., and Schwartz, M.D. (2015). "Male Peer Support Theory", in F.T. Cullen, P. Wilcox, J.L. Lux, and C.L. Jonson (eds.), Sisters in Crime Revisited: Bringing Gender into Criminology (pp. 302-323). New York: NY: Oxford University Press.

van Dijk, J. (2011). "Quantitative Criminology: Crime and Justice Statistics across Nations", in C.J. Smith, S.X. Zhang, and R. Barberet, Routledge Handbook of Criminology: An international perspective. London, England: Routledge.

Gartner, R. (1990). “The Victims of Homicide: A Temporal and Cross-national Comparison”, American Sociological Review 55(1), 92-106.

Gartner, R., Kathryn B., and Pampel, F.C. (1990). "Gender Stratification and the Gender Gap in Homicide Victimization”, Social Problems 37(4), 593-612. doi:10.2307/800584

Hayes, A.F. (2013). Introduction to Mediation, Moderation, and Conditional Process Analysis: A Regression-based Approach. New York, NY: The Guilford Press.

Hester, M., Kelly, L., and Radford, J. (1996). Women, Violence, and Male Power: Feminist Activism, Research, and Practice. UK: Open University Press Buckingham.

Holter, Ø.G. (1995). "Masculinities in Context: On Peace issues and Patriarchal Orders", in I. Breines, R.W. Connell, and I. Eide (eds.), Males Roles, Masculinities and Violence. Paris, France: United Nations Educational, Scientific and Cultural Organization.

Howard, G.J., and Smith, T.R. (2003). "Understanding Cross-National Variations of Crime Rates in Europe and North America”, in K. Aromaa, S. Leppa, S. Nevala, and N. Ollus (eds.), Crime and Criminal Justice in Europe and North America 1995-1997: Report on the sixth United Nations Survey on Crime Trends and Criminal Justice Systems. Helsinki, Finland: European Institute for Crime Prevention and Control. Retrieved from https://www.unodc.org/documents/data-and-analysis/Crime-statistics/ HEUNI_1995-1997.pdf

Hunnicutt, G. (2009). "Varieties of Patriarchy and Violence Against Women: Resurrecting "Patriarchy" as a Theoretical Tool", Violence Against Women 15(5), 553-573. doi:10.1177/1077801208331246

Inglehart, R., and Norris, P. (2003). Rising Tide: Gender Equality and Cultural Change around the World. New York, NY: Cambridge University Press.

Kaya, Y., and Cook, K.J. (2010). "A Cross-National Analysis of Physical Intimate Partner Violence against Women", International Journal of comparative sociology 51(6), 423-444.

Kimmel, M.S., and Messner, M.A. (2001). Men's Lives ( ${ }^{\text {th }}$ ed.). Boston: Allyn and Bacon.

Koeppel, M.D.H., Rhineberger-Dunn, G.M., and Mack, K.E. (2015). "Cross-National Homicide: A Review of the Current Literature", International Journal of Comparative and Applied Criminal Justice 39(1), 47-85. doi:10.1080/01924036.2013.836676

Kornhauser, R.R. (1978). Social Sources of Delinquency: An Appraisal of Analytic Models. Chicago, IL: University of Chicago Press.

Kutner, M.H., Nachtsheim, C.J., and Neter, J. (2004). Applied Linear Regression Models (4th ed.). New York, NY: McGraw-Hill Education

LaFree, G. (1999). "A Summary and Review of Cross-National Comparative Studies of Homicide", in M.D. Smith, and M.A. Zahn (eds.), Homicide: A Sourcebook of Social Research (pp. 24-49). Thousand Oaks, California: Sage.

Lauritsen, J.L., and Heimer, K. (2008). "The Gender Gap in Violent Victimization, 1973-2004”, Journal of Quantitative Criminology 24(2), 125-147. doi:10.1007/s10940-008-9041-y

Lauritsen, J.L., Heimer, K., and Lynch, J.P. (2009). "Trends in the Gender Gap in Violent Offending: New Evidence from the National Crime Victimization Survey", Criminology 47(2), 361-399.

Lee, M.R., and Shihadeh, E. (1998). "Labor Market Structure, Unemployment, and Crime: The indirect Effect of Low-Skill Jobs on Homicide and Theft in 26 Countries", Sociology of Crime, Law, and Deviance 1, 49-64. 
Mandel, H., and Semyonov, M. (2005). "Family Policies, Wage Structures, and Gender Gaps: Sources of Earnings Inequality in 20 Countries", American Sociological Review 70(6), 949-967. doi:10.1177/000312240507000604

Messerschmidt, J.W. (1993). Masculinities and Crime. Lanham, MD.: Rowman \& Littlefield Publisher, Inc. Messner, S.F., and Sampson, R.J. (1991). "The Sex Ratio, Family Disruption, and Rates of Violent Crime: The Paradox of Demographic Structure", Social Forces 69(3), 691-713. doi:10.1093/sf/69.3.693

Messner, S.F., and Rosenfeld, R. (1997). "Political Restraint of the Market and Levels of Criminal Homicide: A Cross-National Application of Institutional Anomie Theory", Social Forces 75(4), 1393-1416.

Messner, S.F., and Rosenfeld, R. (2007). Crime and the American Dream (4th ed.). Belmont, CA: Thomson Wadsworth.

Myers, R.H. (1990). Classical and Modern Regression with Applications (2nd ed.). Boston, MA: Duxbury Press.

Neapolitan, J.L. (1994). 2Cross-National Variations in Homicides: The Case of Latin America", International Criminal Justice Review 4, 4-22.

Neumayer, E. (2003). "Good Policy can lower Violent Crime: Evidence from a Cross-National Panel of Homicide rates, 1980-97”, Journal of Peace Research 40(6), 619-640.

Nivette, A.E. (2011). "Cross-National Predictors of Crime: A Meta-Analysis", Homicide Studies 15(2), 103-131. doi:10.1177/1088767911406397

The OECD Development Centre's Social Institutions and Gender Index (n.d.). “What is SIGI?”. Retrieved from https://www.genderindex.org/

Pickett, K.E., and Wilkinson, R.G. (2014). "Income Inequality and Health: A Causal Review", Social Science \& Medicine 128, 316-326. doi:10.1016/j.socscimed.2014.12.031

Pratt, T.C., and Godsey, T.W. (2002). "Social Support and Homicide: A Cross-National Test of an Emerging Criminological Theory", Journal of Criminal Justice 30, 589-601.

Pridemore, W.A. (2011). "Poverty Matters: A Reassessment of the Inequality-Homicide Relationship in Cross-National studies”, British Journal of Criminology 51(5), 739-772. doi:10.1093/bjc/azr019

Pridemore, W.A. (2002). "Vodka and Violence: Alcohol Consumption and Homicide Rates in Russia", Am J Public Health 92(12), 1921-1930.

Pridemore, W.A., and Freilich, J. (2005). "Gender Equity, Traditional Masculine Culture, and Female Homicide Victimization”, Journal of Criminal Justice 33, 213-223. doi:10.1016/j.jcrimjus.2005.02.002

Rogers, M.L., and Pridemore, W.A. (2013). "The Effect of Poverty and Social Protection on National Homicide Rates: Direct and Moderating Effects”, Social Science Research 42(3), 584-595. doi:http:// dx.doi.org/10.1016/j.ssresearch.2012.12.005

Rossow, I. (2001). "Alcohol and Homicide: A Cross-Cultural Comparison of the Relationship in 14 European Countries”, Addiction 96(1s1), 77-92. doi:10.1046/j.1360-0443.96.1s1.7.x

Runciman, W.G. (1966). Relative deprivation and social justice: a study of attitudes to social inequality in twentiethcentury England. London, UK: Pelican Books Ltd.

Russell, D.E.H. (1984). The politics of rape: The victim's perspective (2nd ed.). New York: Madison Books.

Savage, J., Bennett, R.R., and Danner, M. (2008). "Economic Assistance and Crime: A Cross-National Investigation”, European Journal of Criminology 5(2), 217-238. doi:10.1177/1477370807087645

Schwartz, J., and Steffensmeier, D. (2015). "Can the Gender Gap in Offending be Explained?”, in F.T. Cullen, P. Wilcox, J.L. Lux, and C.L. Jonson (eds), Sisters in Crime Revisited: Bringing Gender into Criminology (pp. 229-260). New York. NY: Oxford University Press.

Simons, R.J. (1975). The Contemporary Woman and Crime. Washington, DC: National Institute of Mental Health.

Solt, F. (2008). "Economic Inequality and Democratic Political Engagement", American Journal of Political Science 52(1), 48-60. doi:10.1111/j.1540-5907.2007.00298.x

Spencer, N. (2004). “The Effect of Income Inequality and Macro-Level Social Policy on Infant Mortality and Low Birth Weight in Developed Countries-A Preliminary Systematic Review", Child Care Health Development 30(6), 699-709. doi:10.1111/j.1365-2214.2004.00485.x 
Stamatel, J.P. (2014). "Explaining Variations in Female Homicide Victimization Rates across Europe", European Journal of Criminology 11(5), 578-600. doi:10.1177/1477370814537941

Stevens, J.P. (2009). Applied Multivariate Statistics for the Social Sciences ( $5^{\text {th }}$ edition). London, UK and New York, NY: Routledge.

Teorell, J., Charron, N., Dahlberg, S., Holmberg, S., Rothstein, B., Sundin, P., and Svensson, R. (2013). “The Quality of Government Basic Dataset". Retrieved from: http://qog.pol.gu.se/data

Titterington, V.B. (2006). "A Retrospective Investigation of Gender Inequality and Female Homicide Victimization”, Sociological Spectrum 26(2), 205-236. doi: 10.1080/02732170500463429

UNOCD (2013). "Global Study on Homicide". Vienna: Austria. Retrieved from https://www.unodc. org/documents/gsh/pdfs/2014_GLOBAL_HOMICIDE_BOOK_web.pdf

Vieraitis, L.M., Britto, S., and Kovandzic, T.V. (2007). "The Impact of Women's Status and Gender Inequality on Female Homicide Victimization Rates", Feminist Criminology 2, 57-73. doi:10.1177/1557085106294187

West, C., and Zimmerman, D.H. (1987). "Doing Gender", Gender \& Society 1(2), 125-151. doi:10.1177/0891243287001002002

Whaley, R.B. (2001). "The Paradoxical Relationship between Gender Inequality and Rape: Toward a Refined Theory”, Gender \& Society 15(4), 531-555. doi:10.1177/089124301015004003

Whaley, R.B., and Messner, S.F. (2002). "Gender Equality and Gendered Homicides", Homicide Studies 6(3), 188-210. doi:10.1177/108876790200600302

Wilkinson, R.G. (2005). The Impact of Inequality: How to Make Sick. Societies Healthier. New York: The New Press.

Wilkinson, R.G. (1996). Unhealtby Societies: The Afflictions of Inequality. New York: Routledge.

Wolf, A., Gray, R., and Fazel, S. (2014). "Violence as a Public Health Problem: An Ecological Study of 169 Countries”, Social Science \& Medicine 104(100), 220-227. doi: 10.1016/j.socscimed.2013.12.006

Wolfgang, M.E., and Ferracuti, F. (1967). The Subculture of Violence: Towards an Integrated Theory in Criminology (Vol. 4). London: Tavistock Publications.

Yodanis, C.L. (2004). "Gender Inequality, Violence against Women, and Fear: A Cross-National Test of the Feminist Theory of Violence Against Women", Journal of Interpersonal Violence 19(6), 655-675. doi:10.1177/0886260504263868 
